\title{
PENGEMBANGAN MODEL MANAJEMEN KURIKULUM BERBASIS PENGUATAN PENDIDIKAN KARAKTER UNTUK MENINGKATKAN MUTU PEMBELAJARAN DI SEKOLAH DASAR
}

\author{
Subekti Kusumadewi \\ SD Masehi Kudus \\ Email: $\underline{\text { s.kusumadewi81@gmail.com }}$
}

\section{Info Artikel}

Sejarah Artikel:

Diserahkan 13 September 2019

Direvisi 13 November 2019

Disetujui 18 November 2019

Keywords:
curriculum management,
character education, quality of
learning

\section{Abstract}

The purpose of this research is to solve the problems in elementary schools especially in the application of learning that still does not prioritize character education.

This research methods is a type of research and development with reference to Borg and Gall model with only seven steps, including: (1) potential and problems, (2) data collection, (3) product design, (4) product validation, (5) revision products, (6) product trials, and (7) product revision. Data obtained through observation, interviews, questionnaires, and documentation. Sources of data are Class IV students and Class IV teachers at Masehi Kudus Elementary School, Tanwirul Qulub School, and $2^{\text {nd }}$ Panjunan School.

The results of the effectiveness test show that "Curriculum Management Based on Strengthening Character Education for Improving the Quality of Learning in Elementary Schools is effectively used in learning in Class IV Elementary Schools Theme "Beautiful Togetherness" Sub Theme 1 "Diversity of My Nation's Culture” with the average results of individual completeness in Masehi Elementary School reaches 91\%, while in Tanwirul Qulub Elementary School and $2^{\text {nd }}$ Panjunan Elementary School reached $82 \%$. The classical completeness of the three elementary schools is also very high with an average classical completeness of almost 100\%. The classical completeness in the three elementary schools in a row is at Masehi Kudus Elementary School reaching 100\%, at Tanwirul Qulub Elementary School and $2^{\text {nd }}$ Panjunan Elementary School are reaching 95\%. Classical absorption is also relatively high with the acquisition in each elementary school as follows: at Masehi Kudus Elementary School by 91\%, at Tanwirul Qulub Elementary School and $2^{\text {nd }}$ Panjunan Elementary School by $82 \%$.

\begin{abstract}
Abstrak
Tujuan penelitian ini untuk memecahkan permasalahan di sekolah dasar khusunya dalam penerapan pembelajaran yang masih belum mengedepankan pendidikan karakter.

Metode penelitian ini merupakan jenis penelitian pengembangan (research and development) dengan mengacu pada model Borg dan Gall dengan tujuh langkah saja, di antaranya: 1) potensi dan masalah, 2) pengumpulan data, 3) desain produk, 4) validasi produk, 5) revisi produk, 6) uji coba produk, dan 7) revisi produk. Data diperoleh melalui observasi, wawancara, kuesioner, dan dokumentasi. Sumber data yakni peserta didik Kelas IV dan guru kelas IV di SD Masehi Kudus, SD Tanwirul Qulub, dan SD 2 Panjunan. Hasil uji efektivitas menunjukkan bahwa Manajemen Kurikulum Berbasis Penguatan Pendidikan Karakteruntuk Meningkatkan Mutu Pembelajaran di Sekolah Dasar efektif digunakan dalam pembelajaran di Kelas IV Sekolah Dasar Tema 1 "Indahnya Kebersamaan" Sub Tema 1 "Keberagaman Budaya Bangsaku" dengan hasil rata-rata ketuntasan individual di SD Masehi Kudus mencapai 91\%, adapun di SD Tanwirul Qulub dan SD 2 Panjunan mencapai 82\%. Ketuntasan klasikal ketiga SD juga sangat tinggi dengan rata-rata ketuntasan klasikal hampir mencapai $100 \%$. Adapun ketuntasan klasikal di ketiga SD secara berturut-turut adalah di SD Masehi Kudus mencapai 100\%, di SD Tanwirul Qulub dan SD 2 Panjunan mencapai 95\%. Daya serap klasikal juga tergolong tinggi dengan perolehan di masing-masing sekolah sebagai berikut: di SD Masehi Kudus sebesar 91\%; di SD Tanwirul Qulub dan SD 2 Panjunan sebesar 82\%.
\end{abstract}

(C) 2019 Universitas Muria Kudus 
Subekti Kusumadewi

PENGEMBANGAN MODEL MANAJEMEN KURIKULUM BERBASIS PENGUATAN ... REFLEKSI EDUKATIKA : Jurnal Ilmiah Kependidikan 10 (1) Desember 2019. Hlm. 87-96

\section{PENDAHULUAN}

Kualitas atau mutu pendidikan selalu menjadi tujuan yang ingin diperjuangkan oleh semua pihak yang berkecimpung di dunia pendidikan. Baik pemerintah pusat, pemerintah daerah, sampai dengan organisasi penyelenggara satuan pendidikan dalam hal ini sekolah, selalu berupaya agar pendidikan yang diselenggarakan mempunyai kualitas yang baik. Era globalisasi merupakan era persaingan sangat ketat terkhusus bagi dunia pendidikan, termasuk tentang kualitas atau mutu pendidikan. Bagi sekolah yang dapat mempertahankan mutunya, maka sekolah tersebutlah yang mampu dan dapat mempertahankan eksistensinya di dunia pendidikan.

Istilah kualitas atau mutu sudah menjadi bagian dari keseharian kita yang mengapresiasikan sesuatu yang unggul, baik, dan layak untuk suatu produk barang, trendi, eksklusif, hingga berkonotasi mahal. Istilah kualitas atau mutupun sudah merasuk ke berbagai obyek yang tidak saja dalam bentuk produk barang, jasa, tetapi sudah menjadi citra penilaian sesuatu pemikiran, perilaku, maupun kebiasaan hidup manusia yang unggul, bermanfaat bagi kehidupan manusia dan dapat mengubah kehidupan manusia menjadi lebih baik. Pengertian kualitas atau mutu masih merupakan pembicaraan yang argumentatif oleh para pakar kualitas atau mutu, sehingga masingmasing memiliki definisi yang berbeda satu dengan lain. Implikasi pentingnya mutu membawa pengaruh pada praktik manajemen sehingga menghasilkan konsep manajemen mutu. Manajemen adalah mengurus atau mengelola. Manajemen menurut Mundir (dalam Barnawi, 2017) manajemen dapat berarti bagaimana cara mengatur, membimbing, dan memimpin semua orang yang menjadi bawahannya agar usaha yang sedang dikerjakan dapat mencapai tujuan yang telah ditetapkan sebelumnya. Fungsi-fungsi manajemen mencakup perencanaan, pengorganisasian, pelaksanaan, dan pengawasan. Manajemen juga berarti ilmu sekaligus seni mengelola sumber daya yang lain untuk mencapai sasaran yang telah ditetapkan. Manajemen merupakan kekuatan utama di setiap organisasi yang mengkoordinasikan aktivitas-aktivitas dari berbagai sistem untuk mencapai tujuan organisasi.

Berdasarkan dari hasil pengamatan yang telah dilakukan, sebagian besar peserta didik
Sekolah Dasar masih mengalami kesulitan dalam menerima pelajaran dikarenakan masih ada caracara mengajar yang kurang variatif dan kurangnya media pembelajaran yang digunakan dalam proses belajar mengajar. Pembelajaran yang konvensional menjadikan peserta didik jenuh dan bosan, bingung untuk memahami dan kurang bersemangat menerima pelajaran. Peningkatan mutu pembelajaran yang akan disampaikan di sini adalah dengan pengembangan kurikulum yang sudah ada dengan mengintegrasikan pendidikan karakter ke dalam proses pembelajaran agar dapat tercipta mutu pembelajaran yang lebih baik lagi. Pengembangan kurikulum ini dilakukan untuk memenuhi kebutuhan yang dikehendaki masyarakat di daerah tersebut. Kurikulum dikembangkan sesuai dengan kebutuhan dan untuk meningkatkan kualitas atau mutu sekolah. Dalam perspektif kebijakan pendidikan nasional sebagaimana dapat "Kurikulum merupakan seperangkat rencana dan pengaturan mengenai tujuan, isi, dan bahan pelajaran serta cara yang digunakan sebagai pedoman penyelenggaraan pembelajaran untuk mencapai tujuan pendidikan tertentu".

Membangun bangsa dan negara Indonesia agar semakin maju dan berkembang serta berdaya saing dengan negara lain bukan hal yang mudah, dibutuhkan tenaga-tenaga muda bangsa ini yang sungguh kompeten dan bermutu. Dibutuhkan generasi muda yang sungguh berkembang dan menguasai segala bidang serta berpribadi baik, berkarakter kuat sehingga memajukan bangsa ini. Sumber daya manusia yang sungguh bermutu itu hanya mungkin dapat terjadi bila sejak dalam pendidikan, anak-anak kita sungguh belajar dengan giat, bekerja dengan giat, dan juga mengembangkan kepribadian mereka secara baik. Dalam hal ini, mereka juga harus mengembangkan karakter mereka, bukan hanya pengetahuan mereka. Untuk mengembangkan karakter mereka jelas dibutuhkan adanya penguatan pendidikan karakter yang baik sejak mereka belajar di sekolah dasar sampai dengan perguruan tinggi. Lewat penguatan pendidikan karakter yang terencana dan terstruktur dengan baik, diharapkan bahwa generasi muda kita sungguh berkembang sebagai pribadi manusia yang berkarakter.

Penguatan pendidikan karakter perlu mengintegrasikan, memperdalam, memperluas, dan sekaligus menyelaraskan berbagai program 
Subekti Kusumadewi

PENGEMBANGAN MODEL MANAJEMEN KURIKULUM BERBASIS PENGUATAN ...

REFLEKSI EDUKATIKA : Jurnal Ilmiah Kependidikan 10 (1) Desember 2019. Hlm. 87-96

yang sudah dilaksanakan sampai sekarang. Dalam hubungan ini pengintegrasian dapat berupa pemanduan kegiatan kelas, luar kelas di sekolah dan di luar sekolah (masyarakat/komunitas); pemanduan kegiatan intrakurikuler, kokurikuler, dan ekstrakurikuler; pelibatan secara serempak warga sekolah, keluarga, dan masyarakat; pendalaman dan perluasan dapat berupa penambahan dan pengintensifan kegiatan-kegiatan yang berorientasi pada pengembangan karakter peserta didik, penambahan dan penajaman kegiatan belajar anak, dan pengaturan ulang waktu belajar peserta didik di sekolah atau luar sekolah; kemudian penyelarasan dapat berupa penyesuaian tugas pokok guru, Manajemen Berbasis Sekolah, dan fungsi Komite Sekolah sesuai dengan penguatan pendidikan karakter. Tujuan penelitian ini adalah untuk menganalisis pengembangan dan keefektifan model manajemen kurikulum berbasis penguatan pendidikan karakter di sekolah dasar.

\section{METODE PENELITIAN}

Jenis penelitian yang dilakukan adalah penelitian pengembangan (research and development), di mana metode yang digunakan bermanfaat untuk menghasilkan produk tertentu dan menguji keefektfan model tersebut (Sugiyono, 2015). Borg and Gall (2003) mengemukakan "research and development is a powerful strategy for improving practice. It is a process used to develop and validate educational products", yang bermakna bahwa penelitian pengembangan sebagai proses yang digunakan untuk mengembangkan dan memvalidasi produk pendidikan. Produk pendidikan yang dimaksud dalam penelitian dan pengembangan ini mengandung tiga pengertian pokok: (1) produk tersebut tidak hanya meliputi perangkat keras (hardware) seperti modul, buku teks, video, dan film pembelajaran atau perangkat keras yang sejenisnya, tetapi juga perangkat lunak (software) seperti kurikulum, evaluasi, model pembelajaran, prosedur, dan proses pembelajaran, dan lain-lain; (2) produk tersebut dapat berarti produk baru atau memodifikasi produk yang sudah ada; (3) produk yang dikembangkan merupakan produk yang betulbetul bermanfaat bagi dunia pendidikan, terutama bagi guru dalam mempermudah (to facilitate) pelaksanaan pembelajaran; (4) Produk tersebut dapat dipertanggungjawabkan baik secara praktis maupun keilmuan. Maka dapat disimpulkan bahwa penelitian pengembangan adalah suatu proses yang digunakan untuk mengembangkan dan memvalidasi produkproduk yang digunakan dalam pendidikan. Dalam penelitian pengembangan dilakukan validasi produk yaitu menguji efektivitas atau validitas produk yang dikembangkan sehingga produk yang dikembangkan menjadi lebih praktis, efektif, dan efisien.

Lebih lanjut Borg dan Gall (dalam Sugiyono, 2015) menyatakan bahwa penelitian analisis kebutuhan menghasilkan produk yang bersifat hipotetik sering digunakan metode penelitian dasar (basic research). Selanjutnya untuk menguji produk yang masih bersifat hipotetik tersebut, digunakan eksperimen atau action research. Setelah produk teruji dapat diaplikasikan dengan proses pengujian produk lewat eksperimen yang dinamakan penelitian terapan (applied research). Penelitian dan pengembangan bertujuan menemukan, mengembangkan, dan memvalidasi suatu produk. Melalui penelitian dan pengembangan ini, peneliti berusaha mengembangkan produk yang layak dan efektif digunakan dalam pembelajaran sehingga dapat meningkatkan kualitas pembelajaran di sekolah. Produk yang dikembangkan adalah model manajemen kurikulum berbasis penguatan pendidikan karakter menggunakan langkah-langkah yang ada dalam penelitian pengembangan. Metode penelitian yang digunakan dalam studi pendahuluan untuk mengetahui kondisi awal dan analisis kebutuhan pada awal penelitian dilakukan menggunakan metode kualitatif dengan teknik pengumpulan data melalui wawancara dan pengamatan. Pengujian internal dilakukan oleh ahli bidang manajemen kurikulum dan ahli bidang pendidikan karakter dengan menggunakan kuisioner untuk mengetahui kevalidan pengembangan model manajemen kurikulum berbasis penguatan pendidikan karakter pada sekolah dasar.

Pengujian keefektifan pembelajaran menggunakan metode kuantitatif dengan teknik pengumpulan data menggunakan tes pemecahan masalah yang berkaitan dengan sikap perilaku sehari-hari. Pengujian keefektifan menerapkan model true experimental designs, yaitu membandingkan kelompok eksperimen dan kelompok kontrol. Penggunaan metode pretestposttest control group designs ini dilakukan karena dalam penelitian bertujuan untuk membandingkan kemampuan pemecahan 
masalah yang berkaitan dengan pembentukan karakter dalam kehiduan sehari-hari sebelum dan sesudah perlakuan dengan menerapkan manajemen kurikulum berbasis penguatan pendidikan karakter.

Untuk dapat mengkaji beberapa variabel pokok yang telah ditetapkan dalam penelitian ini, maka penelitian ini menggunakan metode penelitian dan pengembangan atau research and development. Borg and Gall (dalam Putra, 2012) menjelaskan sepuluh langkah dalam penelitian dan pengembangan, yang dapat dijabarkan sebagai berikut 1) Penelitian dan pengumpulan data (research and information collecting), 2) Perencanaan (planning), 3) Pengembangan draf produk (develop preliminary form of product), 4) Uji coba lapangan awal (preliminary field testing), 5) Merevisi hasil uji coba (main product revison), 6) Uji coba lapangan (main field testing), 7) Penyempurnaan produk hasil uji lapangan (operational produk revision), 8) $\mathrm{Uji}$ pelaksanaan lapangan (operational field testing), 9) Penyempurnaan produk akhir (final produk revision), 10) Diseminasi dan implementasi (dissemination and implementation)

Skematik kegiatan yang dilakukan dalam pengembangan model manajemen kurikulum berbasis penguatan pendidikan karakter di sekolah dasar dapat dilihat pada gambar sebagai berikut.

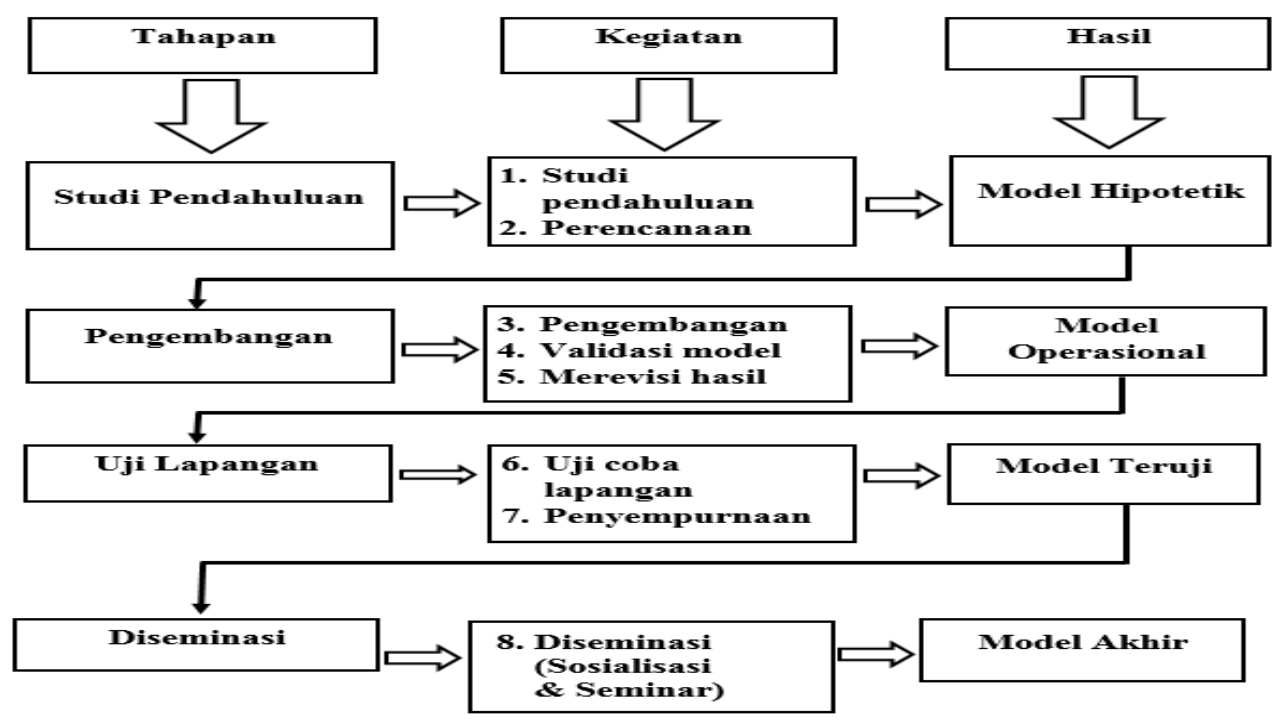

Gambar 3.1. Pengembangan model manajemen kurikulum berbasis PPK di sekolah dasar.

\section{HASIL PEMBAHASAN}

Pada analisis kebutuhan dilakukan analisis awal untuk mengetahui perkiraan atas kebutuhan dalam pengembangan model manajemen kurikulum berbasis penguatan pendidikan karakter yang bisa dilakukan. Tahapan yang dilakukan dalam mengidentifikasi analisis kebutuhan penelitian awal berguna untuk menunjang penelitian yang dilakukan yaitu pengembangan model manajemen kurikulum berbasis penguatan pendidikan karakter untuk peningkatan mutu pembelajaran di sekolah dasar yang diperlukan, sehingga pelaksanaan penelitian dapat berjalan dengan baik dan target kurikulum juga tercapai.
Sebelum model manajemen kurikulum berbasis penguatan pendidikan karakter dikembangkan untuk pembelajaran di kelas, terlebih dahulu dilakukan penelitian awal di kelas yang telah dipilih untuk implementasi model setelah model tersebut dikembangkan. Penelitian awal dalam rangka analisis kebutuhan tersebut diharapkan dapat mengetahui kondisi awal sebelum model diterapkan dan apakah model yang akan diterapkan sesuai dengan kebutuhan guru kelas maupun peserta didik tersebut. Analisis kebutuhan yang dilakukan dengan menyebarkan angket terbuka kepada guru tanpa ada alternatif pilihan jawaban sehingga pendapat guru dapat tersalurkan dengan lebih rinci. Angket yang disebarkan kepada guru 


\section{Subekti Kusumadewi \\ PENGEMBANGAN MODEL MANAJEMEN KURIKULUM BERBASIS PENGUATAN ... REFLEKSI EDUKATIKA : Jurnal Ilmiah Kependidikan 10 (1) Desember 2019. Hlm. 87-96}

memuat beberapa aspek diantaranya adalah mengenai manajemen kurikulum yang saat ini digunakan di sekolah dasar, apakah tepat dalam pengembangan manajemen kurikulum tersebut. Aspek lain yaitu bagaimana implementasi pembelajaran berbasis penguatan pendidikan karakter yang sudah berjalan di kelas oleh guru, kebutuhan dan komponen apa saja yang perlu dikembangkan dalam pembelajaran di kelas.

Desain pengembangan model manajemen kurikulum dilakukan dengan pengelolaan kurikulum yang sistemik dengan pengembangan kurikulum dokumen 1 berbasis penguatan pendidikan karakter perlu mengintegrasikan nilai-nilai karakter yang akan diterapkan. Langkah-langkah pengembangan yang bisa dilakukan yaitu.

1. Langkah pertama yang harus dilakukan dalam pengembangan kurikulum berbasis penguatan pendidikan karakter adalah telaah nilai-nilai karakter yang sudah dilaksanakan pada dokumen kurikulum sekolah. Sekolah harus mengidentifikasi bagian-bagian dari kurikulum sekolah yang terdiri dari latar belakang pengembangan kurikulum, visi, misi, tujuan sekolah, struktur dan muatan kurikulum, pengembangan diri, dan kalender akademik. Telaah dilakukan oleh tim pengembang kurikulum sekolah melalui forum diskusi.

2. Langkah kedua adalah penyusunan rencana aksi pengembangan penguatan pendidikan karakter. Pengembangannya dapat dilakukan dengan mengintegrasikan kegiatan intrakurikuler, kokurikuler, dan ekstrakurikuler. Model manajemen kurikulum yang dikembangkan adalah berbasis penguatan pendidikan karakter. Adapun desain model pengembangannya dibuat sistematis sehingga dapat dibuat sebagai garis pedoman atau suatu peta pembelajaran karena model ini memperlihatkan keseluruhan proses belajar mengajar yang baik, sekalipun tidak menggambarkan secara rinci setiap komponennya.

Desain model ini juga memperlihatkan hubungan antara elemen yang satu dengan yang lain serta menyajikan suatu pola urutan yang dapat dikembangkan dalam suatu rencana untuk mengajar. Berikut ini gambaran desain pengembangan manajemen kurikulum berbasis penguatan pendidikan karakter di sekolah dasar.

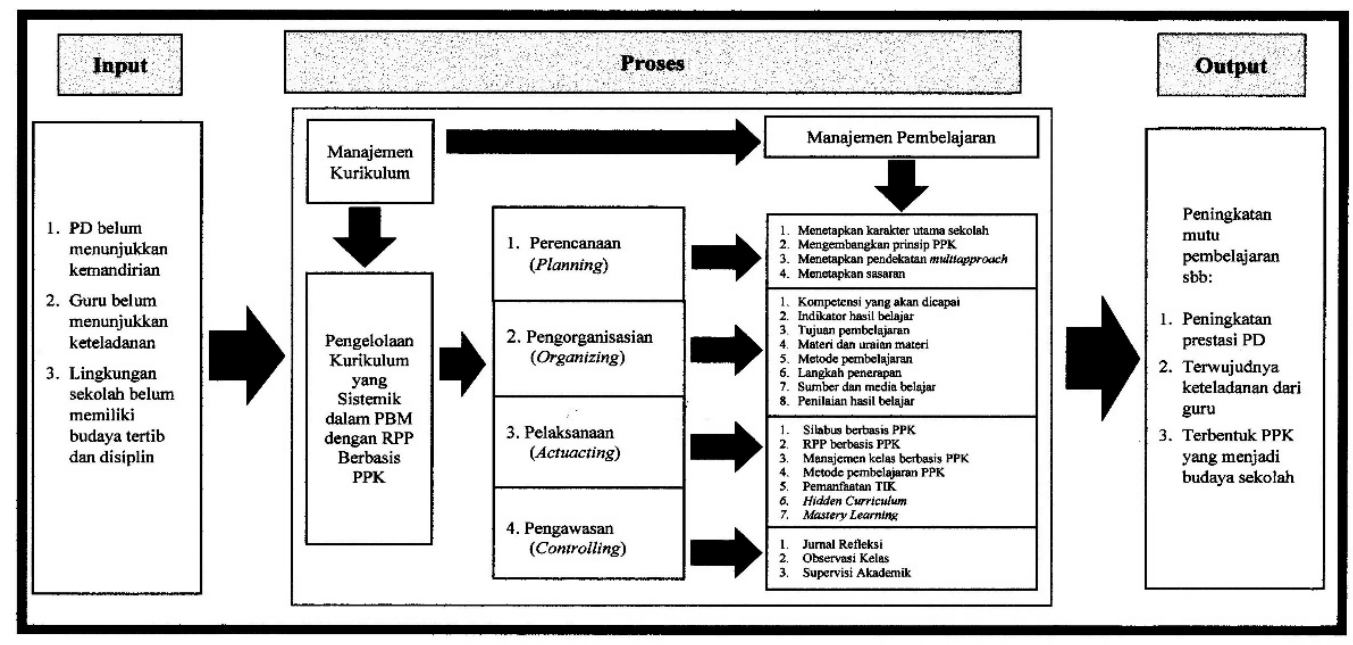

Produk yang dihasilkan dari penelitian ini adalah model manajemen kurikulum berbasis penguatan pendidikan karakter untuk peningkatan mutu pembelajaran di Sekolah Dasar, dengan komponen model sebagai berikut.

1. Input

Input berasal dari beberapa temuan awal di lapangan diantaranya pertama, peserta didik yang belum menunjukkan kemandirian dalam mengikuti proses belajar mengajar; kedua, guru belum mampu menunjukkan keteladanan sikap dan perilaku selama proses belajar mengajar; ketiga, lingkungan sekolah yang belum memiliki budaya tertib dan disiplin. 
Subekti Kusumadewi

PENGEMBANGAN MODEL MANAJEMEN KURIKULUM BERBASIS PENGUATAN ...

REFLEKSI EDUKATIKA : Jurnal Ilmiah Kependidikan 10 (1) Desember 2019. Hlm. 87-96

2. Proses

Proses merupakan kegiatan manajemen kurikulum yang sistemik dalam mengelola proses belajar mengajar dengan menggunakan pembelajaran berbasis Penguatan Pendidikan Karakter. Adapun proses yang muncul selama pengelolaan manajemen kurikulum didukung oleh adanya empat tahapan yaitu: pertama, perencanaan (planning) di mana sekolah harus menetapkan karakter utama sekolah, mengembangkan prinsip Penguatan Pendidikan Karakter, menetapkan pendekatan multiapproach, dan menetapkan sasaran; kedua, pengorganisasian (organinizing) yang terdiri dari menyiapkan kompetensi yang akan dicapai, indicator hasil belajar, tujuan pembelajaran, materi dan uraian materi, metode pembelajaran, langkah penerapan metode pembelajaran, sumber dan media belajar, dan penilaian hasil belajar; ketiga, pelaksanaan (actuacting) di mana guru mempersiapkan silabus berbasis Penguatan Pendidikan Karakter, RPP berbasis Penguatan Pendidikan Karakter Penguatan Pendidikan Karakter, manajemen kelas berbasis Penguatan Pendidikan Karakter, metode pembelajaran berbasis Penguatan Pendidikan Karakter, pemanfaatan TIK, memunculkan hidden curriculum, dan adanya mastery learning; keempat, pengawasan (controlling) terhadap proses belajar mengajar dengan adanya jurnal refleksi baik dari guru dan peserta didik, kepala sekolah juga melakukan observasi kelas dan supervisi akademik berkala.

\section{Output}

Output yang diharapkan adanya peningkatan mutu pembelajaran khususnya dalam prestasi peserta didik dalam bidang akademik dan non akademik, keteladanan dari para guru dalam sikap dan perilaku khususnya selama proses belajar mengajar, dan juga terbentuknya Penguatan Pendidikan Karakter pada akhirnya bisa menjadi budaya sekolah dan dilakukan oleh semua warga sekolah.

Uji coba penelitian ini dilakukan di 3 sekolah di Kabupaten Kudus, yaitu SD Masehi Kudus, SD Tanwirul Qulub, dan SD 2 Panjunan. Pada uji coba ini SD Tanwirul Qulub dan SD 2 Panjunan digunakan sebagai kelas kontrol. Sedangkan SD Masehi Kudus sebagai kelas eksperimen. Pembelajaran dilakukan oleh guru dan peneliti sebagai pengamat. Subyek penelitian terdiri dari 55 peserta didik pada kelas kontrol yaitu 27 peserta didik dari SD Tanwirul Qulub dan 29 peserta didik dari SD 2 Panjunan. Sedangkan subyek pada kelas eksperimen sebanyak 32 peserta didik dari SD Masehi Kudus. Berdasarkan rincian uji efektivitas, peneliti menerapkan proses belajar mengajar tuntas (mastery learning). Adapun rincian hasil temuan tersebut dapat dilihat pada tabel rekapitulasi ketuntasan belajar sebagai berikut.

Tabel 1. Rekapitulasi ketuntasan belajar

\begin{tabular}{|c|c|c|c|c|c|c|c|}
\hline Parameter & Sekolah & Pkn & B. Indo & IPA & IPS & SBDP & Rata-rata \\
\hline \multirow{3}{*}{$\begin{array}{c}\text { Ketuntasan } \\
\text { Individual }\end{array}$} & SD Masehi Kudus & $90 \%$ & $91 \%$ & $92 \%$ & $90 \%$ & $90 \%$ & $91 \%$ \\
\hline & SD Tanwirul Qulub & $82 \%$ & $83 \%$ & $82 \%$ & $83 \%$ & $83 \%$ & $82 \%$ \\
\hline & SD 2 Panjunan & $80 \%$ & $83 \%$ & $82 \%$ & $80 \%$ & $81 \%$ & $81 \%$ \\
\hline \multirow{3}{*}{$\begin{array}{c}\text { Ketuntasan } \\
\text { Klasikal }\end{array}$} & SD Masehi Kudus & $100 \%$ & $100 \%$ & $100 \%$ & $100 \%$ & $100 \%$ & $100 \%$ \\
\hline & SD Tanwirul Qulub & $100 \%$ & $93 \%$ & $93 \%$ & $96 \%$ & $93 \%$ & $95 \%$ \\
\hline & SD 2 Panjunan & $93 \%$ & $93 \%$ & $93 \%$ & $97 \%$ & $97 \%$ & $95 \%$ \\
\hline \multirow{3}{*}{$\begin{array}{c}\text { Daya Serap } \\
\text { Klasikal }\end{array}$} & SD Masehi Kudus & $90 \%$ & $91 \%$ & $92 \%$ & $90 \%$ & $90 \%$ & $91 \%$ \\
\hline & SD Tanwirul Qulub & $82 \%$ & $83 \%$ & $82 \%$ & $83 \%$ & $83 \%$ & $82 \%$ \\
\hline & SD 2 Panjunan & $80 \%$ & $83 \%$ & $82 \%$ & $80 \%$ & $81 \%$ & $81 \%$ \\
\hline
\end{tabular}


Subekti Kusumadewi

PENGEMBANGAN MODEL MANAJEMEN KURIKULUM BERBASIS PENGUATAN ...

REFLEKSI EDUKATIKA : Jurnal Ilmiah Kependidikan 10 (1) Desember 2019. Hlm. 87-96

Berdasarkan kelima pengembangan nilai utama karakter (relihius, nasionalisme, mandiri, gotong royong, dan integritas) diperoleh rata-rata nilai sikap dan persentase perolehan nilai sikap pada setiap rentang nilai sesuai kriteria yang telah ditetapkan. Adapun perolehan nilai sikap sosial peserta didik dapat dilihat pada tabel 2 berikut.

Tabel 2. Rekapitulasi Nilai Sikap Sosial

\begin{tabular}{|c|c|c|c|c|c|c|}
\hline \multicolumn{2}{|c|}{ Nama Sekolah } & Religius & $\begin{array}{c}\text { Nasiona } \\
\text { lisme }\end{array}$ & Mandiri & $\begin{array}{l}\text { Gotong } \\
\text { Royong }\end{array}$ & Integritas \\
\hline \multirow{4}{*}{$\begin{array}{l}\text { SD Masehi } \\
\text { Kudus }\end{array}$} & $\begin{array}{c}\text { Sangat baik }(3,20- \\
4,00)\end{array}$ & $91 \%$ & $91 \%$ & $88 \%$ & $84 \%$ & $91 \%$ \\
\hline & $\begin{array}{c}\text { Baik } \\
(2,80-3,19)\end{array}$ & $9 \%$ & $9 \%$ & $12 \%$ & $16 \%$ & $9 \%$ \\
\hline & $\begin{array}{c}\text { Cukup baik }(2,40- \\
2,79)\end{array}$ & $0 \%$ & $0 \%$ & $0 \%$ & $0 \%$ & $0 \%$ \\
\hline & $\begin{array}{l}\text { Kurang } \\
(<2,40)\end{array}$ & $0 \%$ & $0 \%$ & $0 \%$ & $0 \%$ & $0 \%$ \\
\hline \multirow{4}{*}{$\begin{array}{l}\text { SD Tanwirul } \\
\text { Qulub }\end{array}$} & $\begin{array}{c}\text { Sangat baik }(3,20- \\
4,00)\end{array}$ & $89 \%$ & $89 \%$ & $81 \%$ & $81 \%$ & $89 \%$ \\
\hline & $\begin{array}{c}\text { Baik } \\
(2,80-3,19)\end{array}$ & $11 \%$ & $11 \%$ & $19 \%$ & $19 \%$ & $11 \%$ \\
\hline & $\begin{array}{c}\text { Cukup baik }(2,40- \\
2,79)\end{array}$ & $0 \%$ & $0 \%$ & $0 \%$ & $0 \%$ & $0 \%$ \\
\hline & $\begin{array}{l}\text { Kurang } \\
(<2,40)\end{array}$ & $0 \%$ & $0 \%$ & $0 \%$ & $0 \%$ & $0 \%$ \\
\hline \multirow{4}{*}{ SD 2 Panjunan } & $\begin{array}{c}\text { Sangat baik }(3,20- \\
4,00)\end{array}$ & $86 \%$ & $83 \%$ & $83 \%$ & $83 \%$ & $79 \%$ \\
\hline & $\begin{array}{c}\text { Baik } \\
(2,80-3,19) \\
\end{array}$ & $14 \%$ & $17 \%$ & $17 \%$ & $17 \%$ & $21 \%$ \\
\hline & $\begin{array}{c}\text { Cukup baik }(2,40- \\
2,79)\end{array}$ & $0 \%$ & $0 \%$ & $0 \%$ & $0 \%$ & $0 \%$ \\
\hline & $\begin{array}{l}\text { Kurang } \\
(<2,40)\end{array}$ & $0 \%$ & $0 \%$ & $0 \%$ & $0 \%$ & $0 \%$ \\
\hline
\end{tabular}

Penilaian aspek keterampilan peserta didik meliputi penilaian lima muatan pelajaran sebagaimana penilaian pengetahuan peserta didik. Berikut ini pada tabel 3 dipaparkan hasil penilaian keterampilan peserta didik pada setiap muatan pelajaran yaitu jumlah keseluruhan nilai peserta didik dan rata-rata nilai yang diperoleh peserta didik di kelas.

Tabel 3 Rekapitulasi Nilai Keterampilan

\begin{tabular}{|c|c|c|c|c|c|c|}
\hline \multirow{2}{*}{ Responden } & $\begin{array}{c}\text { Perolehan Nilai Peserta } \\
\text { Didik }\end{array}$ & \multicolumn{5}{|c|}{ Mata Pelajaran } \\
\cline { 2 - 7 } & Pkn & B.Indo & IPA & IPS & SBDP \\
\hline \multirow{2}{*}{$\begin{array}{c}\text { SD Masehi } \\
\text { Kudus }\end{array}$} & $\begin{array}{c}\text { Jumlah } \\
\text { Kata-rata Nilai }\end{array}$ & 2865 & 2820 & 2840 & 2815 & 2790 \\
\cline { 2 - 7 } & Keterampilan & 90 & 88 & 89 & 88 & 87 \\
\hline $\begin{array}{c}\text { SD Tanwirul } \\
\text { Qulub }\end{array}$ & $\begin{array}{c}\text { Rata-rata Nilai } \\
\text { Keterampilan }\end{array}$ & 86 & 87 & 87 & 86 & 86 \\
\hline \multirow{3}{*}{\begin{tabular}{c} 
SD 2 Panjunan \\
\cline { 2 - 7 }
\end{tabular}} & $\begin{array}{c}\text { Rata-rata Nilai } \\
\text { Keterampilan }\end{array}$ & 85 & 84 & 86 & 84 & 2430 \\
\hline
\end{tabular}

Model manajemen kurikulum berbasis penguatan pendidikan karakter peningkatan mutu pembelajaran di sekolah dasar dilandasi oleh modifikasi model desain pembelajaran dari
Gerlach and Ely. Model pembelajaran Gerlach dan Ely (1971) merupakan suatu metode perencanaan pengajaran yang sistematis. Model pembelajaran ini menjadi suatu garis pedoman 
atau suatu peta perjalanan pembelajaran karena dalam desain ini diperlihatkan keseluruhan proses belajar mengajar yang baik, sekalipun tidak menggambarkan secara rinci setiap komponennya. Dalam model ini juga diperlihatkan hubungan antara elemen yang satu dengan yang lainnya serta menyajikan suatu pola urutan yang dapat dikembangkan dalam suatu rencana untuk mengajar.Keseluruhan desain model manajemen kurikulum berbasis penguatan pendidikan karakter untuk peningkatan mutu pembelajaran di sekolah dasar terdiri dari 3 bagian yaitu input, proses, dan output.

Materi yang dipilih berhubungan dengan materi kelas IV tema 1 "Indahnya Kebersamaan", sub tema 1 "Keberagaman Budaya Bangsaku". Materi yang dirumuskan lebih dahulu dikaitkan dengan pengembangan karakter peserta didik. Pemilihan pokok bahasan yang spesifik berguna untuk membatasi ruang lingkup agar lebih jelas. Pengaitan materi dengan pengembangan karakter dapat meningkatkan motivasi belajar peserta didik dan menjadikan pembelajaran lebih bermakna. Pengintegrasian pengembangan karakter dalam suatu pembelajaran sangat sesuai dengan peserta didik. Dengan demikian peserta didik menjadi lebih termotivasi dalam pembelajaran karena sudah memiliki karakter yang baik yang siap megikuti pembelajaran.

Yang tidak kalah penting adalah munculnya Hidden Curriculum mengkaji berbagai penjelasan maupun materi yang tidak disampaikan dalam kurikulum resmi yang diajarkan di sekolah, tetapi ditanamkan melalui serangkaian aktivitas yang berlangsung di sekolah. Terdapat dua aspek dalam Hidden Curriculum yang muncul di sekolah dasar yang diteliti yaitu aspek struktural (organisasi) dan aspek budaya. Dua aspek ini menjadi contoh dan panduan untuk melihat dan mendengar dalam berlangsungnya Hidden Curriculum di sekolah.

Aspek struktural menjelaskan tentang pembagian kelas, berbagai kegiatan sekolah di luar kegiatan belajar (misalnya kegiatan ekstrakurikuler), berbagai fasilitas yang disediakan sekolah (misalnya fasilitas lapangan olahraga, fasilitas perpustakaan, fasilitas ruang multimedia, fasilitas laboratorium, fasilitas tempat ibadah). Fasilitas juga mencakup barangbarang yang ada di sekolah yang dapat mendukung proses pembelajaran di sekolah. Termasuk di dalamnya adalah buku teks dan berbagai program komputer yang diajarkan di sekolah. Aspek kultural mencakup norma sekolah, etos kerja keras, peran dan tanggung jawab, relasi sosial antar pribadi dan antar kelompok, konflik antar pelajar, ritual, dan perayaan ibadah, toleransi, kerja sama, kompetisi, ekspetaksi guru terhadap peserta didik serta disiplin waktu.

Proses belajar mengajar pada akhirnya memunculkanhidden curriculum yang memang muncul secara spontanitas dari guru dan juga peserta didik. Hal tersebut lebih banyak mengarah kepada hal yang bersifat pengembangan dan pendidikan karakter peserta didik sendiri. Hidden curriculum juga muncul dengan guru memberi teladan lewat peristiwaperistiwa yang menjadi pengingat bahwa ada halhal baik yang biasa terus dilakukan peserta didik baik secara berkala maupun rutin. Guru juga memberikan teladan sikap perilaku serta menanamkan nilai-nilai religius yang terus menerus selama proses belajar mengajar.

Keunggulan pembelajaran dengan pengaitan pendidikan karakter selain menjadikan pembelajaran lebih bermakna karena berdasarkan lingkungan terdekat peserta didik, juga sebagai upaya pengenalan dan muaranya adalah menjaga sikap dan perilaku peserta didik agak berkarakter baik. Guru diharapkan dapat mengintegrasikan nilai-nilai karakter dalam pembelajaran. Dalam pengintegrasian ini tentunya harus disesuaikan dengan materi yang disampaikan, perkembangan peserta didik dan juga metode yang digunakan.

Hasil penelitian ini memiliki persamaan dan perbedaan dengan riset Chaliyyah (2019), Eka (2018), Fathurrochman (2017), Giarti (2019), Khotimah (2019), Lazwardi (2017), Maisaro (2018), Nasbi (2017), Ngadiso (2016), Perdana (2017), Rahman et al (2017), Rusilawati (2012), Subiantoro dan Karwanto (2016). Adapun persamaannya pada fokus penelitian mengenai manajemen kurikulum dan pendidikan karakter. Sedangkan perbedaanya ada pada sudut pandang untuk melihat fokus penelitian sehingga hasil penelitiannya berbeda.

\section{SIMPULAN}

Berdasarkan hasil penelitian pengembangan model manajemen kurikulum berbasis penguatan pendidikan karakter untuk peningkatan mutu pembelajaran di sekolah dasar dapat disimpulkan sebagai berikut.

1. Penelitian dan pengembangan ini menghasilkan model manajemen kurikulum berbasis penguatan pendidikan karakter untuk 
Subekti Kusumadewi

PENGEMBANGAN MODEL MANAJEMEN KURIKULUM BERBASIS PENGUATAN ...

REFLEKSI EDUKATIKA : Jurnal Ilmiah Kependidikan 10 (1) Desember 2019. Hlm. 87-96

peningkatan mutu pembelajaran di sekolah dasar. Model ini ditujukan untuk pembelajaran di kelas IV SD pada tema tema 1 "Indahnya Kebersamaan", sub tema 1 "Keberagaman Budaya Bangsaku”.Perangkat pendukung pembelajaran yang terdiri dari silabus dan RPP untuk pembelajaran dikelas IV SD tema 1 "Indahnya Kebersamaan", sub tema 1 "Keberagaman Budaya Bangsaku". Buku panduan model manajemen kurikulum berbasis penguatan pendidikan karakter untuk peningkatan mutu pembelajaran di Sekolah Dasar berisi panduan pengajaran dan pembelajaran serta penyusunan pembelajaran berbasis penguatan pendidikan karakter di sekolah dasar. Kemudian baik model perangkat pendukung dan buku panduan model telah teruji kevalidanya melalui validasi dari pakar dengan skor baik dari masing-masing aspek yang divalidasi. Sehingga model yang dikembangkan layak dan valid untuk diimplementasikan secara terbatas dilapangan.

2. Model yang dihasilkan dinyatakan efektif diterapkan di Sekolah Dasar untuk pembelajaran di kelas IV SD pada tema tema 1 "Indahnya Kebersamaan", sub tema 1 "Keberagaman Budaya Bangsaku". Hal ini yang dibuktikan dengan tingginya ketuntasan belajar peserta didik di ketiga sekolah tempat penelitian, rata-rata ketuntasan individual di SD Masehi Kudus mencapai 91\%, adapun di SD Tanwirul Qulub dan SD 2 Panjunan mencapai $82 \%$. Ketuntasan klasikal ketiga SD juga sangat tinggi dengan rata-rata ketuntasan klasikal hampir mencapai $100 \%$ adapun ketuntasan klasikal di ketiga SD secara berturut-turut adalah di SD Masehi Kudus mencapai $100 \%$, di SD Tanwirul Qulub dan SD 2 Panjunan mencapai 95\%.Daya serap klasikal juga tergolong tinggi dengan perolehan dimasing-masing SD sebagai berikut: di SD Masehi Kudus sebesar 91\%; di SD Tanwirul Qulub dan SD 2 Panjunan sebesar $82 \%$. Disamping itu melalui model manajemen kurikulum berbasis penguatan pendidikan karakter ini juga meningkatkan aspek sikap dan keterampilan peserta didik yang dibuktikan dengan tinggi rata-rata penilaian aspek sikap maupun pengetahuan.

\section{DAFTAR PUSTAKA}

Arikunto, Suharsimi. 2016. Prosedur Penelitian Suatu Pendekatan Praktik. Jakarta: Rineka Cipta.

Asmani, Jamal M. 2013. Buku Panduan Internalisasi Pendidikan Karakter di Sekolah. Jogjakarta: Diva Press.

Barnawi, Arifin. 2017. Sistem Penjaminan Mutu Pendidikan. Yogyakarta: Ar - Ruzz Media.

Chaliyyah, Nafisatul. 2019. Development of Learning Management of E-Learning in Demak Public High School. Educational Management, 8 (1): 1-8.

Creswell, John. 2016. Research Design Pendekatan Metode Kualitatif, Kuantitatif, dan Campuran. Yogyakarta: Pustaka Pelajar.

Eka Andriani, Silvya. 2018. Implementasi Program PPK Melalui Kegiatan Pembiasaan Dalam Peningkatan Mutu Sekolah. Educational Management, 7 (9): 10-21.

Fathurrochman, Irwan. 2017. Implementasi Manajemen Kurikulum Dalam Upaya Meningkatkan Mutu Santri Pondok Pesantren Hidayatullah/Panti Asuhan Anak Soleh Curup. TADBIR : Jurnal Studi Manajemen Pendidikan, 1(01): 85104.

Giarti, Sri. 2016. Manajemen Kurikulum Dan Pembelajaran Berbasis ICT. Satya Widya, 32 (2): 117-126.

Khotimah, Desy Nurlaida. 2019. Implementasi Program Penguatan Pendidikan Karakter (PPK) Melalui Kegiatan 5s Di Sekolah Dasar. Inopendas Jurnal Ilmiah Kependidikan, 2 (1): 28-31.

Lazwardi, Dedi. 2017. Manajemen Kurikulum Sebagai Pengembangan Tujuan Pendidikan. Al-Idarah: Jurnal Kependidikan Islam, 7 (1): 99-112. 
Maisaro, Atik., Wiyono, Bambang Budi dan Arifin, Imron. 2018. Manajemen Program Penguatan Pendidikan Karakter Di Sekolah Dasar. JAMP: Jurnal Adminitrasi dan Manajemen Pendidikan, 1 (3): 302312.

Nasbi, Ibrahim. 2017. Manajemen Kurikulum: Sebuah Kajian Teoritis. JURNAL IDAARAH, I (2): 318-330.

Ngadiso. 2016. Developing a Model for Teaching English Usang Curriculum 13 for the Students of SMA Surakarta. Education Sebelas Maret University, 2 (1): 493-503.

Perdana, Novrian Satria. 2018. Implementasi Peranan Ekosistem Pendidikan Dalam Penguatan Pendidikan Karakter Peserta Didik. Refleksi Edukatika : Jurnal Ilmiah Kependidikan, 8 (2): 183-191.

Rachman, Maman., Masrukhi, M., Munandar, Aris dan Suhardiyanto, Andi. 2017. Pengembangan Model Manajemen Pelatihan Dan Pengembangan Pendidikan Karakter Berlokus Padepokan Karakter. Refleksi Edukatika : Jurnal Ilmiah Kependidikan, 8 (1): 16-26.

Rusilawati, Ani. 2012. Pengembangan Model Pembelajaran Better Teaching and
Learning Berkarakter untuk Membekali Kompetensi Pedagogi Peserta Didik Calon Guru. Jurnal Penelitian Pendidikan, 29 (2):83-94.

Subiantoro, Muhammad Dandi dan Karwanto, K. 2016. Manajemen Kurikulum Berbasis Entrepreneurship Di SMA Muhammadiyah 9 Surabaya. Jurnal Dinamika Manajemen Pendidikan, 1 (1): 55-67.

Supriyono, Yusup. 2016. Developing WBI Based Reading Teaching Model in English Model in English Education Department of State University of Siliwangi. Education Sebelas Maret University, 2 (1): 484- 493.

Trisiana, Anita. 2016. Desain Pengembangan Model Pembelajaran Pendidikan Kewarganegaraan Melalui Addie Model untuk Meningkatkan Karakter Peserta Didik di Surakarta. PKn Progresif, 11 (1): 312-330.

Usodo, Budi. 2016. Developing of ProblemBased Learning Model With Metacognitive Strategy to Improve Students' Problemsolving Ability. International Journal of Science and Applied Science: 1 (1): 79-91. 